\title{
Effects of Cimicifugae Rhizoma on the osteogenic and adipogenic differentiation of stem cells
}

\author{
JI-EUN LEE $^{1 *}$, BO-BAE KIM ${ }^{*}$, YOUNGKYUNG KO ${ }^{1}$, SU-HYEON JEONG $^{2}$ and JUN-BEOM PARK ${ }^{1}$ \\ ${ }^{1}$ Department of Periodontics, College of Medicine, The Catholic University of Korea, Seoul 06591; \\ ${ }^{2}$ Department of Rehabilitation Medicine of Korean Medicine, Chungju Hospital of Korean Medicine, \\ College of Korean Medicine, Semyung University, Chungju-si, Chungcheongbuk-do 27429, Republic of Korea
}

Received August 30, 2015; Accepted October 11, 2016

DOI: $10.3892 /$ etm.2016.4010

\begin{abstract}
Cimicifugae Rhizoma, a herb with a long history of use in traditional Oriental medicine is reported to have anti-inflammatory, antioxidant, anti-complement and anticancer effects. The aim of the present study was to evaluate the effects of Cimicifugae Rhizoma extracts on the osteogenic and adipogenic differentiation of human stem cells derived from gingiva. Stem cells derived from gingiva were grown in the presence of Cimicifugae Rhizoma at final concentrations of $0.1,1$ and $10 \mu \mathrm{g} / \mathrm{ml}$. Cell proliferation analyses were performed at day 15 . For osteogenic differentiation experiments, the stem cells were cultured in osteogenic media containing $\beta$-glycerophosphate, ascorbic acid-2-phosphate and dexamethasone, and osteogenic differentiation was evaluated by analysis of osteocalcin expression at 21 days. For adipogenic differentiation experiments, the stem cells were grown in adipogenic induction medium, and the adipogenic differentiation was evaluated by analysis of adipocyte fatty acid-binding protein at day 14 . The cultures grown in the presence of $0.1 \mu \mathrm{g} / \mathrm{ml}$ Cimicifugae Rhizoma showed a significant increase in cellular proliferation at day 15 compared with the control group. The relative osteogenic differentiation in the presence of Cimicifugae Rhizoma for the $0.1,1$ and
\end{abstract}

Correspondence to: Professor Su-Hyeon Jeong, Department of Rehabilitation Medicine of Korean Medicine, Chungju Hospital of Korean Medicine, College of Korean Medicine, Semyung University, 63 Sangbang 4-gil, Chungju-si, Chungcheongbuk-do 27429, Republic of Korea

E-mail: js365a@hanmail.net

Dr Jun-Beom Park, Department of Periodontics, College of Medicine, The Catholic University of Korea, 222 Banpo-daero, Seocho-gu, Seoul 06591, Republic of Korea

E-mail: jbassoonis@yahoo.co.kr

${ }^{*}$ Contributed equally

Key words: adipocytes, cell di fferentiation, herbal medicine, osteoblasts, plant roots, stem cells, cell survival
$10 \mu \mathrm{g} / \mathrm{ml}$ groups was $171.5 \pm 13.7,125.6 \pm 28.7$ and $150.5 \pm 9.0$, respectively, when that of the untreated control group on day 21 was considered to be $100 \%$. The relative adipogenic differentiation at day 14 of the $0.1,1$ and $10 \mu \mathrm{g} / \mathrm{ml}$ groups in the presence of Cimicifugae Rhizoma was 97.5 $\pm 15.0,102.9 \pm 12.8$ and $87.0 \pm 6.8 \%$, respectively when that of the untreated control group on day 14 was considered to be $100 \%$. Within the limits of this study, Cimicifugae Rhizoma increased the proliferation of stem cells derived from the gingiva, and low concentrations of Cimicifugae Rhizoma may increase the osteogenic differentiation of stem cells.

\section{Introduction}

Herbs have been used for thousands of years in traditional Oriental medicine $(1,2)$. Cimicifugae Rhizoma has been used for $>2,000$ years as a typical Chinese herbal medicine (3). Cimicifugae Rhizoma is primarily derived from Cimicifuga heracleifolia Komarov or Cimicifuga foetida Linnaeus (4). It is reported to have various effects, including anti-inflammatory, antioxidant, anticomplement and anticancer activities (3,5-8). Cimicifugae Rhizoma has been shown to be an effective antioxidant that protects DNA and lipids against oxidative stress (3). It has also been suggested to be a useful therapeutic agent for treating hyperpigmentation and as an active component in whitening and/or lightening cosmetics (9).

We have previously isolated and characterized human mesenchymal stem cells (MSCs) from the gingiva (10). These gingiva-derived stem cells have been used for tissue-engineering purposes, including new bone formation $(11,12)$. A previous study demonstrated that Cimicifugae Rhizoma reduced the viability of stem cells derived from the gingiva and indicated that the direct application of Cimicifugae Rhizoma onto oral tissues could potentially induce adverse effects at high doses (13).

The aim of the present study was to evaluate the effects of Cimicifugae Rhizoma extracts on the osteogenic and adipogenic differentiation of human stem cells derived from gingiva. To the best of our knowledge, this investigation is the first to elucidate the effect of Cimicifugae Rhizoma on the osteogenic differentiation of stem cells derived from gingiva. 


\section{Materials and methods}

Materials. Minimum essential medium $\alpha$ ( $\alpha$-MEM), fetal bovine serum (FBS) and trypsin/EDTA solution were purchased from Gibco (Thermo Fisher Scientific, Inc., Waltham, MA, USA). Unless otherwise stated, all other chemicals and reagents were obtained from Sigma-Aldrich (Merck Millipore, Darmstadt, Germany).

Preparation of Cimicifugae Rhizoma extract. Dry roots of Cimicifuga heracleifolia Komarov (500 g) were obtained from Chungju Hospital of Korean Medicine, College of Korean Medicine, Semyung University (Chungju, Korea) were immersed in distilled water and boiled under reflux for $150 \mathrm{~min}$, and the resulting extract was centrifuged at $5,000 \mathrm{xg}$ for $10 \mathrm{~min}$ at room temperature. The supernatant was concentrated to a volume of $300 \mathrm{ml}$ using a rotary evaporator under reduced pressure (Eyela NE-1001; Tokya Rikakikai Co., Ltd., Tokyo, Japan). The concentrates were then freeze-dried in a lyophilizer (Labconco, Kansas, MO, USA) to obtain $92.8 \mathrm{~g}$ solid residue, corresponding to a yield of $18.6 \%(\mathrm{w} / \mathrm{w})$.

Isolation and culture of stem cells derived from gingiva. Healthy gingival tissues were obtained from healthy patients undergoing crown-lengthening procedures. This study was reviewed and approved by the Institutional Review Board of Seoul St. Mary's Hospital, College of Medicine, The Catholic University of Korea, (Seoul, Republic of Korea; KC11SISI0348), and informed consent was obtained from all patients.

The tissues were immediately placed into sterile phosphate-buffered saline (PBS; Welgene, Daegu, South Korea) with $100 \mathrm{U} / \mathrm{ml}$ penicillin and $100 \mu \mathrm{g} / \mathrm{ml}$ streptomycin at $4^{\circ} \mathrm{C}$. The gingival tissue was de-epithelialized, minced, digested with collagenase IV and incubated at $37^{\circ} \mathrm{C}$ in a humidified incubator with $5 \% \mathrm{CO}_{2}$ and $95 \% \mathrm{O}_{2}$. The non-adherent cells were washed with PBS after $24 \mathrm{~h}$, supplied with $\alpha$-MEM (Gibco) containing 15\% FBS (Gibco), $100 \mathrm{U} / \mathrm{ml}$ penicillin and $100 \mu \mathrm{g} / \mathrm{ml}$ streptomycin (both Sigma-Aldrich), $200 \mathrm{mM}$ L-glutamine (Sigma-Aldrich) and $10 \mathrm{mM}$ ascorbic acid 2-phosphate (Sigma-Aldrich), and fed every 2-3 days.

Analysis of cell proliferation. The stem cells were plated at a density of $1.0 \times 10^{4}$ cells/well. The cells were incubated in $\alpha$-MEM, which included 15\% FBS, $100 \mathrm{U} / \mathrm{ml}$ penicillin, $100 \mu \mathrm{g} / \mathrm{ml}$ streptomycin and $1 \mathrm{mM}$ ascorbic acid 2-phosphate, in the presence of Cimicifugae Rhizoma at final concentrations ranging from 0.1 to $10 \mu \mathrm{g} / \mathrm{ml}$, specifically: 0 (untreated control), $0.1,1$ and $10 \mu \mathrm{g} / \mathrm{ml}$.

Cell proliferation analyses were performed at day 15 . A solution of WST-8 [2-(2-methoxy-4-nitrophenyl)-3-(4-nitrop henyl)-5-(2,4-disulfophenyl)-2H-tetrazolium, monosodium salt] from Cell Counting kit-8 (CCK-8; Dojindo Molecular Technologies, Inc., Tokyo, Japan) was added to the cultures, and the spheres were incubated for $30 \mathrm{~min}$ at $37^{\circ} \mathrm{C}$. The CCK-8 assay identifies viable cells via the formation of a formazan dye from WST- 8 by the oxidative action of mitochondrial dehydrogenases in living cells. The spectrophotometric absorbance of the samples at $450 \mathrm{~nm}$ was measured using a microplate reader (BioTek Instruments, Inc., Winooski, VT, USA).

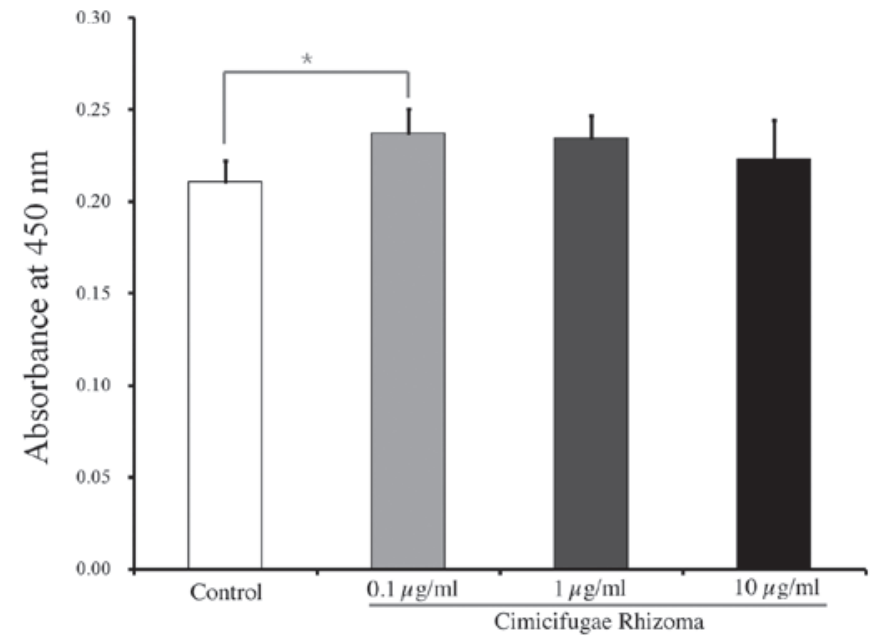

Figure 1. Cell proliferation at day 15 in the presence and absence of Cimicifugae Rhizoma determined by Cell Counting Kit- 8 assay. Results are presented as the means \pm standard deviations ( $n=6$ per group). ${ }^{*} \mathrm{P}<0.05$ vs. the untreated control.

Osteogenic differentiation. The stem cells were plated at a density of $1.6 \times 10^{4}$ cells/chamber in an 8 -chamber slide and then incubated in $\alpha$-MEM, containing 15\% FBS, $100 \mathrm{U} / \mathrm{ml}$ penicillin, $100 \mu \mathrm{g} / \mathrm{ml}$ streptomycin, $10 \mathrm{mM} \beta$-glycerophosphate, $1 \mathrm{mM}$ ascorbic acid 2-phosphate and $100 \mu \mathrm{M}$ dexamethasone in the presence of Cimicifugae Rhizoma at final concentrations of $0.1,1$ and $10 \mu \mathrm{g} / \mathrm{ml}$, respectively. The medium was replaced with fresh induction medium every 3 days. At day 21, the cells were fixed with $4 \%$ paraformaldehyde by incubation for $30 \mathrm{~min}$ at room temperature and the cells were washed with sterile PBS three times. The cells were then treated with $1 \%$ Triton X-100 for $5 \mathrm{~min}$, and washed with PBS three times. Blocking was conducted with $1 \%$ bovine serum albumin (Sigma-Aldrich) in PBS for $30 \mathrm{~min}$ at $4^{\circ} \mathrm{C}$ in the dark. The cells were incubated with a primary antibody against osteocalcin (sc-30044; Santa Cruz Biotechnology, Inc., Dallas, TX, USA) at 1:100 dilution for $1 \mathrm{~h}$ at $4^{\circ} \mathrm{C}$ in the dark. The cells were washed with sterile PBS three times and then incubated with secondary antibodies (sc-53805; Santa Cruz Biotechnology, Inc.) at 1:200 dilution for $1 \mathrm{~h}$ at $4^{\circ} \mathrm{C}$ in the dark. Coverslips were mounted with mounting media (Vector Laboratories, Inc., Burlingame, CA, USA) containing 4',6-diamidine-2'-phenylindole dihydrochloride (DAPI). The cells were observed under a fluorescence microscope (Axiovert 200; Zeiss GmbH, Jena, Germany). Relative osteogenesis was determined with the aid of image analysis software (ImageJ; National Institutes of Health, Bethesda, MD, USA).

Adipogenic differentiation. The stem cells were plated at a density of $1.6 \times 10^{4}$ cells/chamber in an 8 -chamber slide and then incubated with adipogenic induction medium (StemPro ${ }^{\circledR}$ Adipogenesis Differentiation kit; Gibco) in the presence of the Cimicifugae Rhizoma at final concentrations of $0.1,1$ and $10 \mu \mathrm{g} / \mathrm{ml}$, respectively. The medium was replaced with fresh induction medium every 3-4 days. At day 14, the cells were fixed with $4 \%$ paraformaldehyde by incubation for $30 \mathrm{~min}$ at room temperature, and permeabilized in $1 \%$ Triton X-100 with PBS for 5 min. Blocking was conducted with $1 \%$ bovine serum 

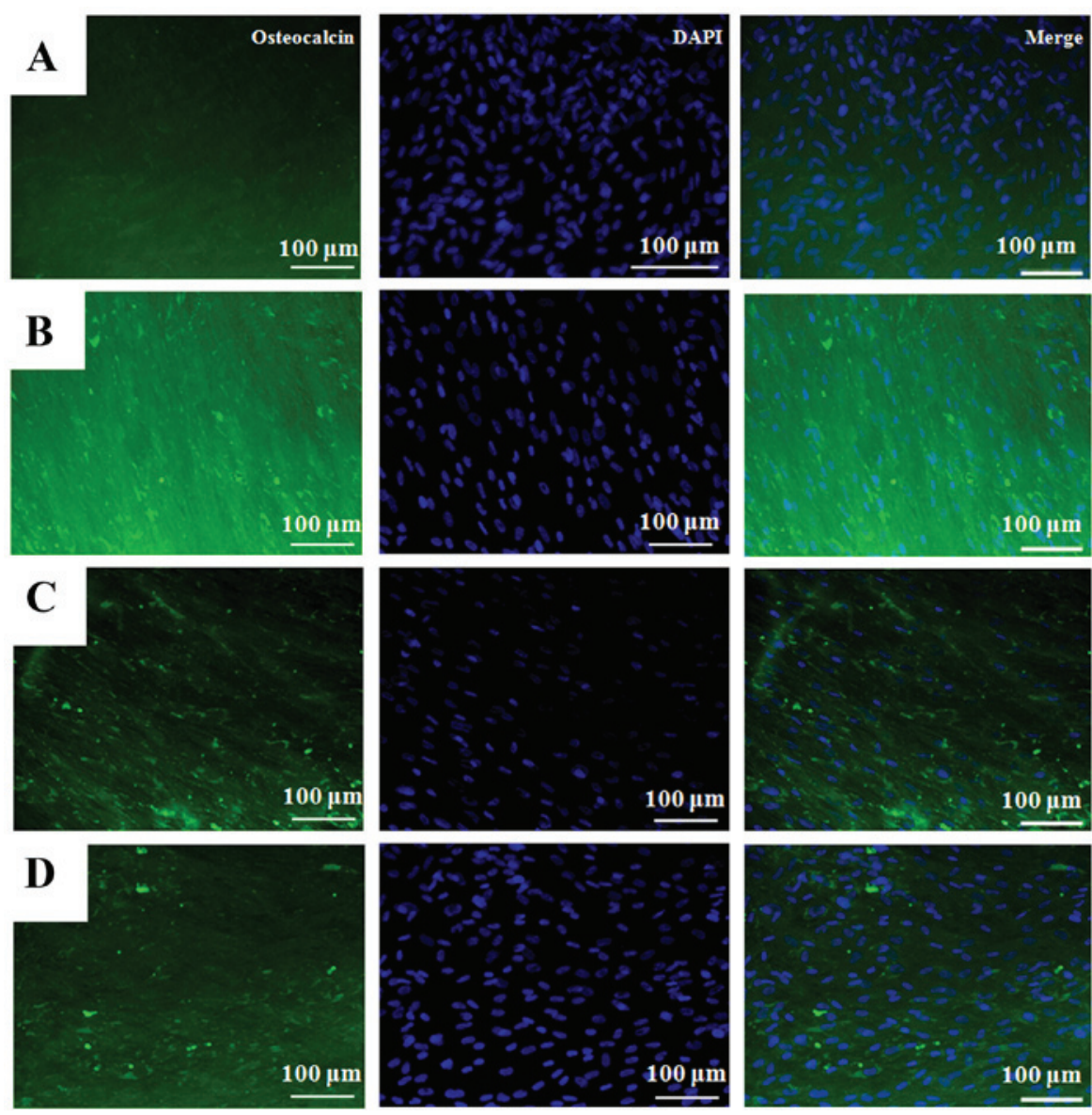

Figure 2. Osteogenic differentiation at day 21. Immunofluorescence staining of cells with osteocalcin antibody with secondary antibody labeled with fluorescein isothiocyanate and/or DAPI. (A) Control, (B) $0.1 \mu \mathrm{g} / \mathrm{ml} \mathrm{Cimicifugae} \mathrm{Rhizoma,} \mathrm{(C)} 1 \mu \mathrm{g} / \mathrm{ml}$ Cimicifugae Rhizoma and (D) $10 \mu \mathrm{g} / \mathrm{ml} \mathrm{Cimicifugae}$ Rhizoma. DAPI, 4',6-diamidine-2'-phenylindole dihydrochloride.

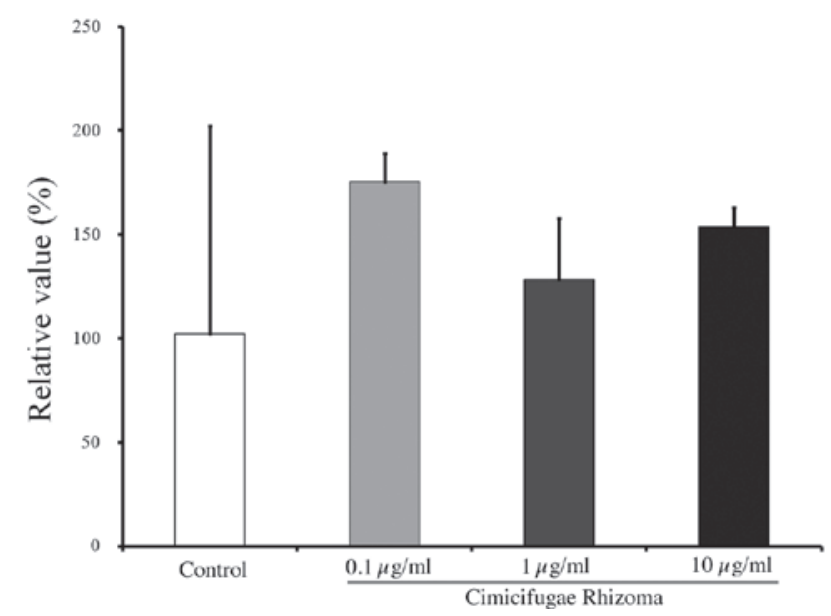

Figure 3. Relative osteogenic differentiation of cells treated with Cimicifugae Rhizoma as determined by analysis of osteocalcin expression. Results are presented as the means \pm standard deviations ( $\mathrm{n}=2$ per group).

albumin (Sigma-Aldrich) in PBS at $4^{\circ} \mathrm{C}$ for $30 \mathrm{~min}$. The cells were incubated with primary antibody against adipocyte fatty acid-binding protein (sc-271529; Santa Cruz Biotechnology, Inc.) for $1 \mathrm{~h}$ at $4^{\circ} \mathrm{C}$ and then incubated with secondary antibodies [goat anti-mouse IgG1 heavy chain (fluorescein isothiocyanate) ab97239; Abcam, Cambridge, UK)] at 1:200 dilution for $1 \mathrm{~h}$ in the dark. The cells were mounted with mounting medium and DAPI. The cells were observed under a fluorescence microscope. Relative adipogenesis was determined with the aid of ImageJ analysis software.

Statistical analysis. Results are presented as the means \pm standard deviations. One-way analysis of variance with Tukey's post hoc test were performed to determine the differences between the groups using commercially available software (SPSS 12 for Windows; SPSS Inc., Chicago, IL, USA). P<0.05 was considered to indicate a statistically significant difference.

\section{Results}

Cell proliferation. The cell proliferation results at day 15 are shown in Fig. 1. The relative values for the cells treated with $0.1,1$ and $10 \mu \mathrm{g} / \mathrm{ml}$ Cimicifugae Rhizoma were 112.5 \pm 6.3 , $111.3 \pm 5.7$ and $105.8 \pm 10.0 \%$, respectively, when the CCK-8 result of the untreated control group on day 21 was considered to be $100 \%(100.0 \pm 5.3 \%)$. The relative value in the CCK-8 assay of $0.1 \mu \mathrm{g} / \mathrm{ml}$ Cimicifugae Rhizoma was significantly different when compared with the control $(\mathrm{P}<0.05)$.

Osteogenic differentiation. Images showing the immunofluorescence staining of osteocalcin in cells treated with Cimicifugae Rhizoma at final concentrations of 0, 0.1, 1 and $10 \mu \mathrm{g} / \mathrm{ml}$ for 21 days are shown in Fig. 2. The relative osteogenic 

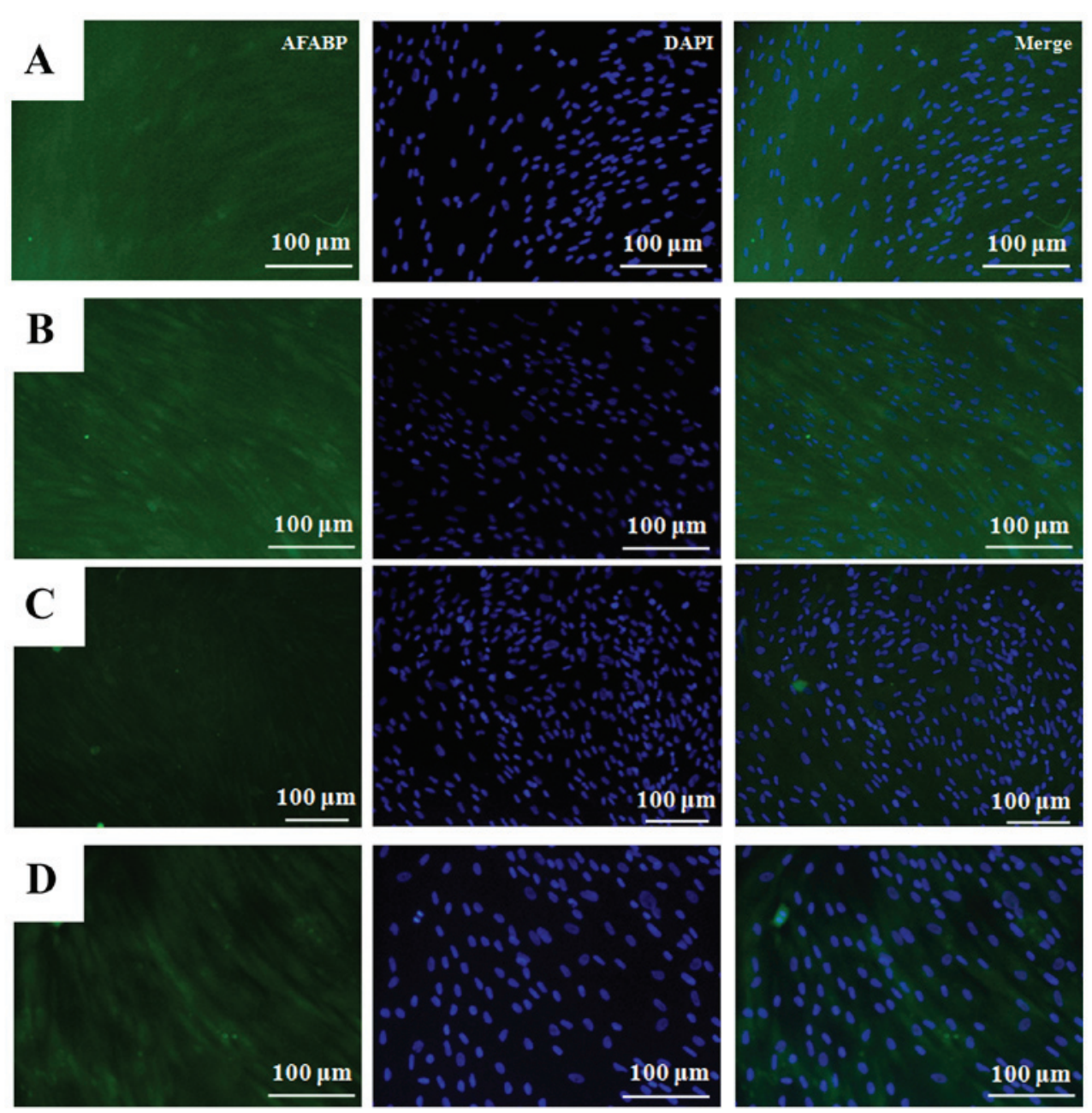

Figure 4. Adipogenic differentiation at day 14. Immunofluorescence staining of cells with AFABP antibody with secondary antibody labeled with fluorescein isothiocyanate and/or DAPI. (A) Control, (B) $0.1 \mu \mathrm{g} / \mathrm{ml}$ Cimicifugae Rhizoma, (C) $1 \mu \mathrm{g} / \mathrm{ml}$ Cimicifugae Rhizoma and (D) $10 \mu \mathrm{g} / \mathrm{ml}$ Cimicifugae Rhizoma. DAPI, 4',6-diamidine-2'-phenylindole dihydrochloride; AFABP, adipocyte fatty acid-binding protein.

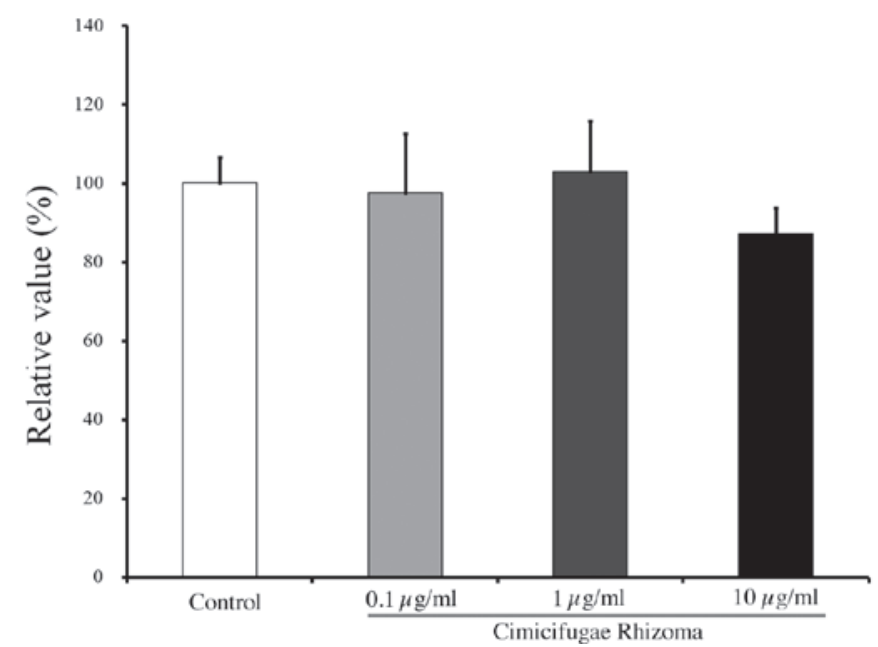

Figure 5. Relative adipogenic differentiation of cells treated with Cimicifugae Rhizoma as determined by analysis of adipocyte fatty acid-binding protein expression. Results are presented as the means \pm standard deviations $(\mathrm{n}=2$ per group)

differentiation percentages of the $0.1,1$ and $10 \mu \mathrm{g} / \mathrm{ml}$ groups were calculated to be $171.5 \pm 13.7,125.6 \pm 28.7$ and $150.5 \pm 9.0 \%$, respectively, when the osteogenic differentiation of the untreated control group on day 21 was considered to be $100 \%$ ( $\mathrm{P}>0.05$; Fig. 3).

Adipogenic differentiation. Images showing the immunofluorescence staining of adipocyte fatty acid-binding protein in cells treated with Cimicifugae Rhizoma at final concentrations of $0,0.1,1$ and $10 \mu \mathrm{g} / \mathrm{ml}$ at day 14 are shown in Fig. 4 . The relative adipogenic differentiation rates of the of $0.1,1$ and $10 \mu \mathrm{g} / \mathrm{ml}$ groups were calculated to be $97.5 \pm 15.0,102.9 \pm 12.8$ and $87.0 \pm 6.8 \%$, respectively, when the adipogenic differentiation of the untreated control group on day 14 was considered to be $100 \%$ (100.0 $\pm 6.5 \%$; P>0.05; Fig. 5).

\section{Discussion}

In this study, the effects of Cimicifugae Rhizoma on the osteogenic and adipogenic differentiation of human MSCs derived from gingiva were evaluated. Cimicifugae Rhizoma at a final concentration of $0.1 \mu \mathrm{g} / \mathrm{ml}$ induced a $71 \%$ increase in osteogenic differentiation compared with the control. However, Cimicifugae Rhizoma treatment did not induce significant differences in adipogenic differentiation when compared with the untreated control. 
Cimicifugae Rhizoma has traditionally been used to treat bone disease in Oriental medicine, and has been reported to increase alkaline phosphatase synthesis in rat calvarial osteoblasts (14). Moreover, a previous study demonstrated that Cimicifugae Rhizoma significantly preserved trabecular bone mass, bone volume, trabecular number, trabecular thickness, structure model index and bone mineral density in ovariectomized mice and may protect against osteoporosis (15). In the present study, enhanced osteogenic differentiation of stem cells was achieved with the aid of Cimicifugae Rhizoma.

The osteogenic differentiation medium comprised $10 \mathrm{mM}$ $\beta$-glycerophosphate, $1 \mathrm{mM}$ ascorbic acid 2-phosphate and $100 \mu \mathrm{M}$ dexamethasone (16). Osteogenic differentiation protocols using $\beta$-glycerophosphate, ascorbic acid and dexamethasone are frequently used in a number of experimental approaches, including tissue engineering and the simple confirmation of differentiation capabilities among particular cell types (17). In a previous study, MSCs derived from bone marrow have been cultured in various base media containing 1-10 mM $\beta$-glycerophosphate, 0.01-4 mM ascorbic acid-2-phosphate and 1-1,000 nM dexamethasone (18).

MSCs have attracted significant interest due to their self-renewing potential and potential for multiple possible clinical uses, particularly in regenerative medicine and tissue engineering $(19,20)$. MSCs have been isolated from bone marrow, adipose tissue, periosteum, trabecular bone, synovium, skeletal muscle and deciduous teeth (19). Mesenchymal stem cells from bone marrow in the iliac crest are usually retrieved under general anesthesia; additionally, there are limitations including pain, morbidity and low cell numbers obtained by harvesting $(20,21)$. Dental pulp from deciduous teeth is a potential source of MSCs with easy accessibility and limited morbidity; however, the amount of dental pulp is limited and ensuring a continuous supply of dental pulp is not possible (22). However, MSCs may be obtained from gingiva relatively easily, with minimal invasiveness at any point in life (10).

The degree of osteoblast differentiation was assessed by the measurement of osteocalcin levels. Current markers of bone formation include the $\mathrm{N}$-terminal propeptide of type I collagen, bone-specific alkaline phosphatase and intact or N-mid-molecule osteocalcin in serum (23). Osteocalcin is an abundant $\mathrm{Ca}^{2+}$-binding protein, comprising three $\gamma$-carboxyglutamic residues, which is a component of the organic matrix of bone and dentin and may be present in other mineralized tissues (24). Osteocalcin originates from osteoblastic synthesis and is deposited into bone or released into circulation (25).

In the present study, adipogenic differentiation was assessed by measuring the amount of adipocyte fatty acid-binding protein. Adipocyte fatty acid-binding protein is reported to regulate systemic glucose and lipid metabolism, and is abundantly expressed by adipocytes (26). Adipocyte fatty acid-binding protein is expressed during adipocyte differentiation (27) and is also applied as a circulating biomarker that is closely associated with obesity and components of the metabolic syndrome (28).

Within the limits of this study, Cimicifugae Rhizoma influenced the proliferation of stem cells derived from the gingiva, and low concentrations of Cimicifugae Rhizoma may induce the osteogenic differentiation of these stem cells.

\section{Acknowledgements}

The present study was supported by the Semyung University Research Grant of 2014.

\section{References}

1. Fabricant DS and Farnsworth NR: The value of plants used in traditional medicine for drug discovery. Environ Health Perspect 109 (Suppl 1): S69-S75, 2001.

2. Jeong SH, Lee JE, Jin SH, Ko Y and Park JB: Effects of Asiasari radix on the morphology and viability of mesenchymal stem cells derived from the gingiva. Mol Med Rep 10: 3315-3319, 2014.

3. Li X, Lin J, Gao Y, Han W and Chen D: Antioxidant activity and mechanism of Rhizoma Cimicifugae. Chem Cent J 6: 140, 2012.

4. Li JX, Kadota S, Li HY, Miyahara T, Wu YW, Seto H and Namba T: Effects of Cimicifugae rhizoma on serum calcium and phosphate levels in low calcium dietary rats and on bone mineral density in ovariectomized rats. Phytomedicine 3: 379-385, 1997.

5. Yim SH, Kim HJ, Park SH, Kim J, Williams DR, Jung DW and Lee IS: Cytotoxic caffeic acid derivatives from the rhizomes of Cimicifuga heracleifolia. Arch Pharm Res 35: 1559-1565, 2012.

6. Lu L, Chen JC, Li Y, Qing C, Wang YY, Nian Y and Qiu MH: Studies on the constituents of Cimicifuga foetida collected in Guizhou Province and their cytotoxic activities. Chem Pharm Bull (Tokyo) 60: 571-577, 2012.

7. Qiu M, Kim JH, Lee HK and Min BS: Anticomplement activity of cycloartane glycosides from the rhizome of Cimicifuga foetida. Phytother Res 20: 945-948, 2006.

8. Kim SJ and Kim MS: Inhibitory effects of cimicifugae rhizoma extracts on histamine, bradykinin and COX-2 mediated inflammatory actions. Phytother Res 14: 596-600, 2000.

9. Jang JY, Lee JH, Kang BW, Chung KT, Choi YH and Choi BT: Dichloromethane fraction of Cimicifuga heracleifolia decreases the level of melanin synthesis by activating the ERK or AKT signaling pathway in B16F10 cells. Exp Dermatol 18: 232-237, 2009.

10. Jin SH, Lee JE, Yun JH, Kim I, Ko Y and Park JB: Isolation and characterization of human mesenchymal stem cells from gingival connective tissue. J Periodontal Res 50: 461-467, 2015.

11. Jin SH, Kweon H, Park JB and Kim CH: The effects of tetracycline-loaded silk fibroin membrane on proliferation and osteogenic potential of mesenchymal stem cells. J Surg Res 192: e1-e9, 2014.

12. Xu QC, Wang ZG, Ji QX, Yu XB, Xu XY, Yuan CQ, Deng J and Yang PS: Systemically transplanted human gingiva-derived mesenchymal stem cells contributing to bone tissue regeneration. Int J Clin Exp Pathol 7: 4922-4929, 2014.

13. Jeong SH, Lee JE, Kim BB, Ko Y and Park JB: Evaluation of the effects of Cimicifugae Rhizoma on the morphology and viability of mesenchymal stem cells. Exp Ther Med 10: 629-634, 2015.

14. Kim DK, Kim T, Pi SH, Pi SH, Kim HA, Choi KS, You HK and Shin HS: Effects of several natural medicines on alkaline phosphatase synthesis in MC3T3-E1 cells. J Korean Acad Periodontol 29: 751-764, 1999.

15. Ahn BS, Yang M, Jang H, Lee HJ, Moon C, Kim JC, Jung U, Jo SK, Jang JS and Kim SH: Evaluation of the antiosteoporotic potential of Cimicifuga heracleifolia in female mice. Phytother Res 26: 663-668, 2012.

16. Park JB: The effects of dexamethasone, ascorbic acid, and $\beta$-glycerophosphate on osteoblastic differentiation by regulating estrogen receptor and osteopontin expression. J Surg Res 173: 99-104, 2012.

17. Langenbach $\mathrm{F}$ and Handschel J: Effects of dexamethasone, ascorbic acid and $\beta$-glycerophosphate on the osteogenic differentiation of stem cells in vitro. Stem Cell Res Ther 4: 117, 2013.

18. Jaiswal N, Haynesworth SE, Caplan AI and Bruder SP: Osteogenic differentiation of purified, culture-expanded human mesenchymal stem cells in vitro. J Cell Biochem 64: 295-312, 1997.

19. Barry FP and Murphy JM: Mesenchymal stem cells: Clinical applications and biological characterization. Int J Biochem Cell Biol 36: 568-584, 2004.

20. Yoshimura $\mathrm{H}$, Muneta $\mathrm{T}$, Nimura A, Yokoyama A, Koga $\mathrm{H}$ and Sekiya I: Comparison of rat mesenchymal stem cells derived from bone marrow, synovium, periosteum, adipose tissue, and muscle. Cell Tissue Res 327: 449-462, 2007. 
21. Park JB, Lee KS, Lee W, Kim HS, Lee KH and Kim IS Establishment of the chronic bone defect model in experimental model mandible and evaluation of the efficacy of the mesenchymal stem cells in enhancing bone regeneration. Tissue Eng Regen Med 10: 18-24, 2013.

22. Park JB, Bae SS, Lee PW, Lee W, Park YH, Kim H, Lee KH and Kim IS: Comparison of stem cells derived from periosteum and bone marrow of jaw bone and long bone in rabbit models. Tissue Eng Regen Med 9: 224-230, 2012.

23. Booth SL, Centi A, Smith SR and Gundberg C: The role of osteocalcin in human glucose metabolism: Marker or mediator? Nat Rev Endocrinol 9: 43-55, 2013.

24. Hauschka PV: Osteocalcin: The vitamin K-dependent $\mathrm{Ca}^{2+}$-binding protein of bone matrix. Haemostasis 16: 258-272, 1986.

25. Gundberg CM, Lian JB and Booth SL: Vitamin K-dependent carboxylation of osteocalcin: Friend or foe? Adv Nutr 3: 149-157, 2012 .
26. Shum BO, Mackay CR, Gorgun CZ, Frost MJ, Kumar RK, Hotamisligil GS and Rolph MS: The adipocyte fatty acid-binding protein aP2 is required in allergic airway inflammation. J Clin Invest 116: 2183-2192, 2006.

27. Shaughnessy S, Smith ER, Kodukula S, Storch J and Fried SK: Adipocyte metabolism in adipocyte fatty acid binding protein knockout mice (aP2-/-) after short-term high-fat feeding: Functional compensation by the keratinocyte [correction of keritinocyte] fatty acid binding protein. Diabetes 49: 904-911, 2000. 28. Xu A, Wang Y, Xu JY, Stejskal D, Tam S, Zhang J, Wat NM, Wong WK and Lam KS: Adipocyte fatty acid-binding protein is a plasma biomarker closely associated with obesity and metabolic syndrome. Clin Chem 52: 405-413, 2006. 